\title{
POTENSI TEPUNG KULIT BUAH MANGGIS (GARCINIA MANGOSTANA L) UNTUK MENINGKATKAN PERTUMBUHAN DAN KELANGSUNGAN HIDUP IKAN NILA (OREOCHROMIS NILOTICUS)
}

\author{
Potential of Mangosteen Rind Flour (Garcinia mangostana L) To Increase Fish Growth \\ and Survival of Tilapia (Oreochromis niloticus)
}

\author{
Darna Susantie, Usy Nora Manurung \\ Program Studi Teknologi Budidaya Ikan Jurusan Perikanan dan Kebaharian \\ Email : darunadayana@gmail.com
}

\begin{abstract}
Abstrak: Ikan membutuhkan pakan dalam pertumbuhan dan kelangsungan hidupnya. Pakan ikan adalah komponen paling penting dalam budidaya ikan. Pakan yang berkualitas bagi ikan adalah pakan yang mudah dicerna, tidak mengandung racun, dan mengandung gizi yang tinggi. Kulit buah manggis dapat dijadikan pakan ikan dalam meningkatkan pertumbuhan dan kelangsungan hidup ikan yang dibudidayakan karena mengandung senyawa xantone yang cukup kuat sebagai antioksidan, antiproliferartif, dan antimicrobial. selain itu mengandung flavonoid, saponin, alkaloid, triterpenoid, tanin, dan polifenol (Suksamrarn, 2003; Mardawati et al., 2008; Puspitasari et al., 2013). Komposisi tepung kulit buah manggis yaitu air 9\%, abu 2,58\%, protein 2,69\%, serat kasar 30,05\%, gula total 6,92\%, dan lainnya (tanin, lemak) 48,76\%. Kegiatan penerapan penelitian Unggulan Perguruan Tinggi ini bertujuan untuk mengetahui pengaruh penambahan tepung kulit buah manggis terhadap pertumbuhan dan kelangsungan hidup ikan nila (Oreochromis niloticus). Waktu pelaksanaan penelitian selama 1 bulan dari tanggal 08 Agustus sampai 10 September 2020 di Kampung Nahepese Kecamatan Manganitu. Prosedur kerja penelitian meliputi beberapa tahap yaitu persiapan pakan uji, persiapan wadah pemeliharaan, persiapan ikan uji, dan pemeliharaan ikan uji. Ikan uji yang digunakan dalam penelitian ini adalah ikan nila berukuran 3-5 cm sebanyak 180 ekor dimana masing-masing wadah didistribusikan 20 ekor ikan. Sedangkan bahan uji yang dipakai adalah tepung kulit buah manggis yang ditambahkan dalam tepung pelet kemudian dicampurkan menjadi merata lalu ditambahkan air secukupnya, dicetak dan dijemur. Laju pertumbuhan harian tertinggi ikan nila selama 30 hari pemeliharaan terdapat pada perlakuan B. Sintasan hidup ikan nila pada kontrol dan perlakuan B yaitu $100 \%$, yang artinya semua ikan uji yang dipelihara hidup semua. Sedangkan pada perlakuan A yaitu 95\%, dimana ada 1 ekor ikan yang meloncat keluar happa.
\end{abstract}

Kata kunci: manggis, ikan nila, pertumbuhan, tingkat kelangsungan hidup.

\begin{abstract}
Fish need feed for growth and survival. Fish feed is the most important component in fish farming. Quality feed for fish is food that is easily digested, does not contain toxins, and contains high nutrition. Mangosteen rind can be used as fish feed in increasing the growth and survival of cultivated fish because it contains xanthone compounds which are strong enough as antioxidants, antiproliferarts, and antimicrobials. besides containing flavonoids, saponins, alkaloids, triterpenoids, tannins, and polyphenols (Suksamrarn, 2003; Mardawati et al., 2008; Puspitasari et al., 2013). The composition of mangosteen rind flour is $9 \%$ water, $2.58 \%$ ash, $2.69 \%$ protein, $30.05 \%$ crude fiber, $6.92 \%$ total sugar, and $48.76 \%$ others (tannins, fat). This research application activity of Higher Education Excellence aims to determine the effect of adding mangosteen rind flour to the growth and survival of tilapia (Oreochromis niloticus). The time for conducting the research is 1 month from August 8 to September 102020 in Nahepese Village, Manganitu District. The research work procedure includes several stages, namely preparation of test feed, preparation of maintenance containers, preparation of test fish, and rearing of test fish. The test fish used in this study were 180 tilapia fish measuring 3-5 cm in which 20 fish were distributed in each container. While the test material used is mangosteen rind flour which is added to the pellet flour then mixed evenly and then added with enough water then printed and dried. The highest daily growth rate of tilapia for 30 days of maintenance was found in treatment $B$. The survival rate of tilapia in control and treatment $B$ was $100 \%$, which means that all of the tested fish that were reared were all alive. Whereas in treatment A, it was $95 \%$, where 1 fish jumped out of the happa.
\end{abstract}

Keyword: mangosteen, tilapia, growth, and survival rate. 


\section{PENDAHULUAN}

Ikan nila merupakan salah satu hasil perikanan darat yang banyak diminati masyarakat karena merupakan sumber protein hewani tinggi (Yue et al., 2016). Ikan nila adalah salah satu komoditi ikan air tawar yang sudah populer dan mempunyai potensi besar untuk dikembangkan di Kabupaten Kepulauan Sangihe. Keunggulan ikan nila adalah mudah di budidaya dan kelangsungan hidup tinggi, pertumbuhan relatif cepat, memiliki toleransi terhadap perubahan lingkungan serta tahan terhadap perubahan kondisi lingkungan. Ikan nila memiliki banyak keunggulan untuk dikembangkan karena sifat biologi yang menguntungkan seperti pertumbuhannya yang cepat, pemakan segala bahan makanan (omnivora), memiliki daya adaptasi yang luas, dan toleransi terhadap kondisi lingkungan cukup tinggi. Ikan nila banyak diminati oleh masyarakat tidak hanya karena rasa dagingnya yang khas tetapi juga karena laju pertumbuhan yang cepat. Kepopuleran ikan nila tidak semata-mata hanya karena laju pertumbuhannya yang cepat tetapi ada faktor lain yang memegang peranan penting adalah cita rasa dagingnya yang khas dan harga jualnya yang terjangkau oleh masyarakat (El-Sayed, 2006 dan Sallata, 2015).

Pakan ikan adalah komponen paling penting dalam budidaya ikan, termasuk ikan nila, karena harga pakan tidak murah. Sebagian besar bahan bakunya diimpor. Pakan ikan itu sendiri terbagi menjadi dua yakni, pakan alami (pakan yang berasal dari alam) dan pakan buatan (pakan olahan manusia). Pakan buatan merupakan faktor utama yang diperhatikan dalam budidaya ikan. Pakan buatan yang berkualitas bagi ikan adalah apabila pakan itu mudah dicerna, tidak mengandung racun, dan mengandung gizi yang tinggi (Afrianto dan Liviawaty, 2005).

Kulit buah manggis banyak terdapat di Kabupaten Kepulauan Sangihe dan belum dimanfaatkan oleh masyarakat. Buah manggis merupakan tanaman di daerah tropis dan sangat bermanfaat. Buah eksotis yang sering dijuluki "Queen of Fruit" ini mempunyai kandungan antioksidan pada kulit dan buahnya (Suksamrarn, 2003). Kulit buah manggis mengandung senyawa yang cukup kuat sebagai antioksidan, antiproliferative, dan antimicrobial yang tidak ditemui pada buah-buahan lainnya (Mardawati et al., 2008). Kulit buah manggis mengandung flavonoid, saponin, alkaloid, triterpenoid, tanin, dan polyphenols (Puspitasari et al., 2013). Kulit buah manggis dapat dijadikan pakan ikan. Untuk itu perlu adanya penelitian tentang "Potensi tepung kulit buah manggis untuk meningkatkan pertumbuhan dan kelangsungan hidup ikan nila”.

\section{METODE PENELITIAN}

\section{Waktu dan Tempat Kegiatan}

Penelitian dilaksanakan di Desa Nahepese pada tanggal 8 Agustus sampai 8 September 2020.

\section{Persiapan Wadah Pemeliharaan dan Sampel Ikan}

Wadah yang dipakai dalam penelitian adalah hapa sebanyak 9 buah yang di pasang di kolam (Gambar 1).

Sampel ikan yang digunakan adalah ikan nila berukuran 3-5 cm sebanyak 180 ekor dan masing-masing wadah berjumlah 20 ekor. Ikan nila yang dimasukkan ke dalam wadah terlebih dahulu di aklimatisasi. Ikan nila yang dipakai dalam penelitian ini yaitu ikan nila yang benar-benar memiliki kualitas yang baik, memiliki ciriciri tidak luka atau tidak cacat pada bagian sirip dan badannya, berwarna cerah dan pergerakannya aktif. 

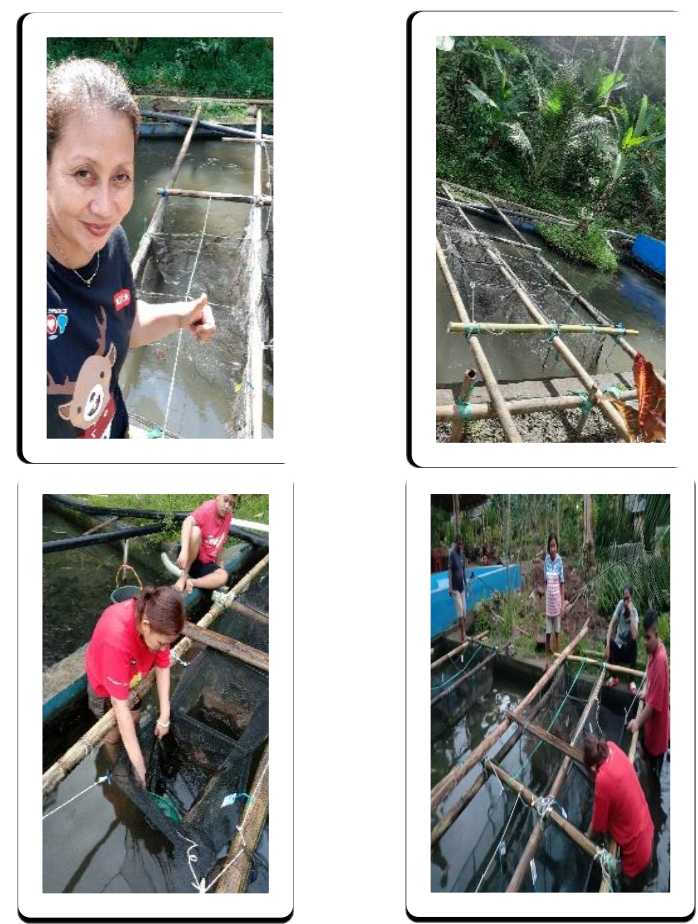

Gambar 1. Wadah Pemeliharaan Ikan Nila (Dok. Pribadi, Agustus 2020)

\section{Pembuatan Pakan Uji}

Pakan uji yang digunakan adalah tepung kulit buah manggis dan tepung pelet. Untuk pembuatan tepung kulit buah manggis, terlebih dahulu kulit buah manggis yang keras dibuang kemudian dicuci bersih, lalu dipotongpotong kecil-kecil dan dijemur di sinar matahari langsung.

Setelah kulit buah manggis benar-benar kering, kemudian dihaluskan dengan blender dan diayak. Tepung kulit buah manggis dimasukkan dalam plastik dan disimpan dalam wadah tertutup. Sedangkan pelet dihaluskan dengan blender lalu diayak dan disimpan dalam wadah. Untuk membuat pakan uji, tepung pelet dan tepung kulit buah manggis dituangkan ke dalam loyang kemudian dicampur sampai merata. Setelah itu ditambahkan air secukupnya lalu diaduk-aduk sampai benar-benar tercampur dan adonan pakan uji bisa dibentuk dengan tangan lalu dimasukkan dalam mesin pencetak pelet. Setelah semua adonan pakan uji dicetak menjadi pelet kemudian dijemur di sinar matahari sampai kering. Setelah benar-benar kering, pakan uji disimpan dalam wadah tertutup dan diberi tanda dengan menggunakan labeling (Gambar 2).
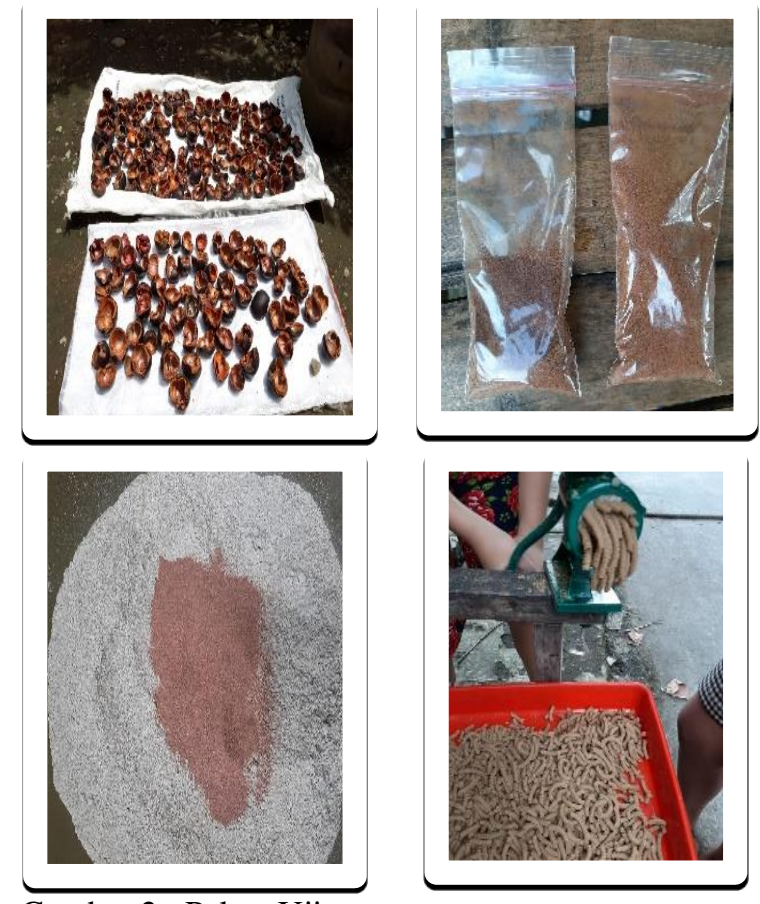

Gambar 2. Pakan Uji

(Dok. Pribadi, July 2020)

\section{Pengambilan Data}

Data yang diambil adalah berat dan panjang tubuh ikan nila dan parameter kualitas air yaitu pengukuran suhu air, $\mathrm{pH}$, nitrat, nitrit, dan amonia. Pengukuran pertumbuhan ikan nila sebanyak 3 kali yaitu hari ke-0 (awal), hari ke-15 (pertengahan) dan hari ke-30 (akhir). Pada pengukuran panjang total dan berat tubuh ikan setiap happa diambil 5 ekor.

\section{Pengontrolan Wadah dan Kualitas Air}

Dalam proses pengontrolan kualitas air dilakukan pemantauan pada setiap wadah. Jika ada kotoran dalam wadah pemeliharaan maka perlu pembersihan dengan mengangkat kotoran yang ada dalam atau sekitar wadah. Pengukuran kualitas air yaitu mengukur suhu, $\mathrm{pH}$, nitrat, nitrit, dan amonia. 


\section{ANALISA DATA}

\section{Pertumbuhan}

Laju pertumbuhan panjang tubuh ikan menggunakan rumus yang digunakan menurut Effendie (1997) adalah sebagai berikut :

$$
\mathbf{L}=\frac{\mathbf{L t}-\mathbf{L o}}{\mathrm{T}}
$$

Keterangan :

$$
\begin{aligned}
& \mathrm{L}=\text { Laju pertumbuhan panjang }(\mathrm{cm} / \text { hari }) \\
& \mathrm{L}_{0}=\text { Panjang awal pemeliharaan }(\mathrm{cm}) \\
& \mathrm{L}_{\mathrm{t}}=\text { Panjang akhir pemeliharaan }(\mathrm{cm})
\end{aligned}
$$

Laju pertambahan berat tubuh ikan menggunakan rumus yang digunakan menurut Effendie (1997) adalah sebagai berikut :

$$
\mathbf{W}=\frac{\mathbf{W t}-\mathbf{W o}}{\mathbf{T}}
$$

Keterangan :

$$
\begin{aligned}
& \mathrm{W}=\text { Laju pertambahan berat }(\mathrm{gr} / \mathrm{hari}) \\
& \mathrm{W}_{0}=\text { Berat awal pemeliharaan }(\mathrm{gr}) \\
& \mathrm{W}_{\mathrm{t}}=\text { Berat akhir pemeliharaan }(\mathrm{gr})
\end{aligned}
$$

\section{Tingkat Keberhasilan Hidup (\%)}

Tingkat keberhasilan hidup menurut De Silva dan Anderson (1995) yaitu:

$$
\mathbf{S R}=\frac{\mathbf{N t}}{\mathbf{N o}} \mathbf{X} 100 \%
$$

Keterangan :

$\mathrm{SR}=$ Survival rate $(\%)$

$\mathrm{N}_{0}=$ Jumlah benih tebar awal (ekor)

$\mathrm{N}_{\mathrm{t}}=$ Jumlah benih pada hari akhir pemeliharaan

\section{HASIL DAN PEMBAHASAN}

\section{Deskripsi Pemeliharaan Ikan Nila}

Sampel ikan nila adalah berjumlah 180 ekor, pada setiap wadah didistribusikan masing-masing 20 ekor ikan yang berukuran $3-5 \mathrm{~cm}$. Pakan yang diberikan adalah tanpa penambahan tepung kulit buah manggis (kontrol) dan penambahan tepung kulit buah manggis dengan dosis yaitu $5 \mathrm{gr} / \mathrm{kg}$, dan $15 \mathrm{gr} / \mathrm{kg}$.

\section{Pertumbuhan Panjang Ikan Nila}

Hasil pengamatan terhadap pertumbuhan ikan nila selama 30 hari pemeliharaan menunjukkan nilai yang berbeda. Peningkatan panjang tubuh ikan nila pada perlakuan dosis tepung kulit buah manggis dalam pakan memiliki nilai lebih tinggi dibandingkan dengan tanpa tepung kulit buah manggis dapat dilihat pada Tabel 1 dan Gambar 3.

Tabel 1. Rata-Rata Laju Pertumbuhan Panjang Tubuh Ikan Nila Selama 30 Hari Pemeliharaan.

\begin{tabular}{cccc}
\hline Perlakuan & $\mathbf{L}_{\mathbf{0}}(\mathbf{c m})$ & $\mathbf{L}_{\mathbf{t}}(\mathbf{c m})$ & $\mathbf{L}(\mathbf{c m})$ \\
\hline Kontrol & 4,6 & 6,8 & 0,1 \\
\hline $\mathbf{A}$ & 4,7 & 7,1 & 0,1 \\
\hline B & 4,5 & 9,7 & 0,2 \\
\hline
\end{tabular}

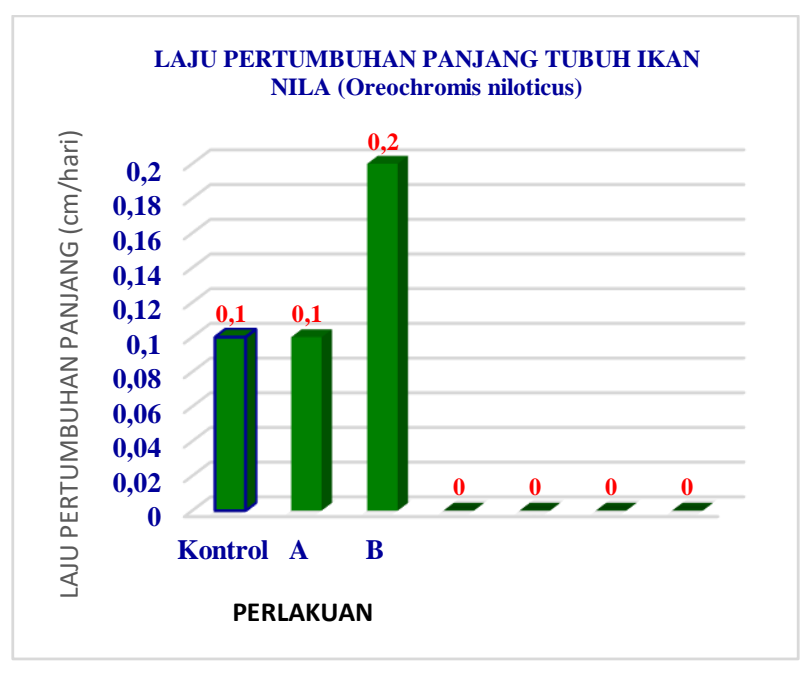

Gambar 3. Rata-Rata Laju Pertumbuhan Panjang Tubuh Ikan Nila Selama 30 Hari Pemeliharaan

Dari Tabel dan Grafik diatas dapat dilihat bahwa laju pertumbuhan panjang ikan nila selama 30 hari pemeliharaan yang tertinggi yaitu perlakuan B (15 gr/pakan). Pertumbuhan panjang rata-rata ikan nila mempunyai hasil yang berbeda. Panjang harian yang tertinggi pada perlakuan B yaitu $0,2 \mathrm{~cm} /$ hari dan diikuti Kontrol yaitu $0,1 \mathrm{~cm} / \mathrm{hari}$, dan perlakuan A yaitu 0,1 $\mathrm{cm} /$ hari.

Pertumbuhan merupakan perubahan bentuk yang diakibatkan pertambahan panjang, berat dan volume 
dalam periode tertentu secara individual. Pertumbuhan dapat diartikan sebagai pertambahan jumlah sel-sel secara mitosis yang pada akhirnya menyebabkan perubahan ukuran jaringan. Pertumbuhan bagi suatu populasi adalah pertambahan jumlah individu, yang mana faktor yang mempengaruhi yaitu faktor internal dan eksternal. Faktor internal adalah faktor yang berasal dari dalam tubuh, seperti genetik/keturunan, umur, jenis kelamin, ketahanan tubuh, penyakit, efisiensi pakan serta kemampuan mencerna makanan. Sedangkan faktor eksternal yaitu faktor-faktor yang berasal dari luar tubuh ikan, seperti kualitas air (parameter lingkungan), pakan, jumlah makanan, kandungan gizi, jumlah populasi, media budidaya, persaingan, pemangsaan, penyakit dan parasit (Lagler, et al., 1962; Effendi, 1997).

Menurut Khairuman dan Amri (2003), bahwa laju pertumbuhan tubuh ikan nila yang dibudidayakan tergantung dari pengaruh fisika dan kimia perairan serta interaksinya. Laju pertumbuhan ikan nila lebih cepat dipelihara di kolam yang airnya dangkal dibandingkan di kolam yang airnya dalam. Hal ini disebabkan karena di perairan dangkal, pertumbuhan tanaman air sangat cepat sehingga ikan nila menjadikannya sebagai makanan.

\section{Pertambahan Berat Ikan Nila}

Hasil pengamatan selama 30 hari pemeliharaan ikan nila mengalami pertambahan berat tubuh. Laju pertambahan berat ikan nila dapat dilihat pada Tabel 2 dan Gambar 4.

Tabel 2. Rata-Rata Laju Pertambahan Berat Ikan Nila Selama 30 Hari Pemeliharaan.

\begin{tabular}{cccc}
\hline Perlakuan & $\mathbf{W}_{\mathbf{0}}(\mathbf{g r})$ & $\mathbf{W}_{\mathbf{t}}(\mathbf{g r})$ & $\mathbf{W}(\mathbf{g r})$ \\
\hline Kontrol & 1,5 & 5,4 & 0,1 \\
\hline $\mathbf{A}$ & 1,6 & 6,1 & 0,2 \\
\hline $\mathbf{B}$ & 1,3 & 11,5 & 0,3 \\
\hline
\end{tabular}

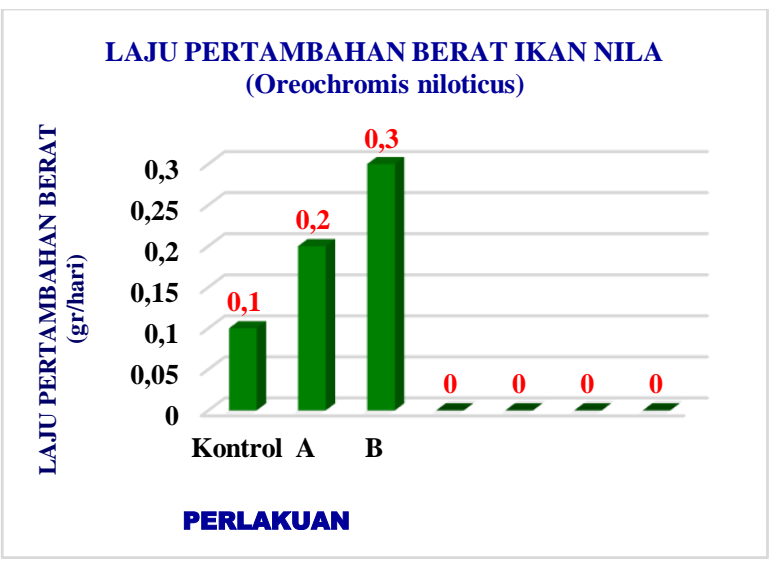

Gambar 4. Rata-Rata Laju Pertambahan Berat Ikan Nila Selama 30 Hari Pemeliharaan

Dari Tabel dan Grafik dapat dilihat bahwa laju pertambahan berat ikan nila selama 30 hari pemeliharaan dimana rata-rata peningkatan pertambahan berat yang tertinggi yaitu perlakuan B (15 gr/pakan). Pertambahan berat rata-rata ikan nila mempunyai hasil yang berbeda. Berat harian yang tertinggi pada perlakuan B yaitu 0,3 gr/hari, diikuti perlakuan A yaitu 0,2 gr/hari, dan Kontrol yaitu $0,1 \mathrm{gr} / \mathrm{hari}$.

Ikan membutuhkan nutrisi untuk bertumbuh dan berkembang. Lovell (1989) mengatakan kebutuhan akan gizi pada ikan adalah jumlah dan jenis asam amino esensial, kandungan protein, kandungan energi pakan dan faktor fisiologis ikan. Campuran yang seimbang dari bahan penyusun pakan merupakan dasar untuk penyusunan formulasi pakan yang sesuai dengan kebutuhan nutrisi ikan (Cho dan Watanabe, 1985). Menurut Halver (1989), bahwa protein merupakan komponen organik terbesar dalam jaringan tubuh ikan adalah sekitar $65-75 \%$ dari total bobot tubuh ikan terdiri dari protein. Menurut Webster dan Lim (2002) bahwa kadar protein optimal dalam menunjang pertumbuhan ikan berkisar antara $28-50 \%$

Kemampuan cerna ikan terhadap bahan baku pakan dipengaruhi oleh beberapa faktor yaitu suhu, sifat kimia air, jenis pakan, ukuran, umur ikan, kandungan gizi pakan, frekuensi pemberian pakan, sifat fisika dan kimia 
pakan serta jumlah dan macam enzim pencernaan yang terdapat di dalam saluran pencernaan ikan (NRC, 1993). Pemanfaatan pakan sangat ditentukan oleh kondisi media hidup dan tingkat kebutuhan larva/benih yang merupakan faktor penentu keberhasilan dalam budidaya. Dalam memilih pakan yang tepat agar efektif pemanfaatannya, ada lima prinsip yang perlu dipertimbangkan yaitu ketepatan dalam hal kuantitas, kualitas (nilai nutrisi dan sanitasi), bentuk dan ukuran, daya tarik, dan ketahanan (stabilitas) di dalam air atau media (Ilyas et al. 1987).

Tingginya pertumbuhan pada semua perlakuan menunjukkan ikan dapat mencerna pakan dengan baik dan nutrisi yang diserap lebih banyak. Fujaya (2004), mengatakan makanan penting bagi pertumbuhan adalah protein, vitamin, mineral, karbohidrat dan lipid di tambah air dan oksigen. Protein, karbohidrat dan lipid harus dihancurkan menjadi zat yang lebih sederhana di dalam saluran pencernaan sebelum dipakai dan dimanfaatkan oleh masing-masing sel. Pertumbuhan jaringan atau organ selain dipengaruhi oleh kualitas makanan, juga dipengaruhi oleh hormon pertumbuhan, baik faktor perangsang pertumbuhan dan penghambat pertumbuhan.

Pertumbuhan panjang maupun pertambahan berat pada ikan tertinggi diperoleh pada perlakuan B (15 gr/pakan) karena kebutuhan tepung kulit buah manggis pada pakan yang diberikan ke ikan nila menunjukkan terdapat pengaruh unsur utama dalam tepung manggis yakni antioksidan berupa karotenoid yang memberikan pengaruh pada proses metabolisme dan pencernaan yang lebih baik.

Menurut Ekawati (2008) bahwa dengan tersedianya karotenoid dalam tubuh ikan maka tersedia bahan baku untuk diubah menjadi senyawa-senyawa penting dalam menunjang hidup larva termasuk untuk tumbuh dan berkembang. Meyers dan Latscha (1997) mengemukakan bahwa karotenoid merupakan substansi penting yang harus terdapat dalam pakan, namun ketersediaannya tetap dalam kondisi optimal.

\section{Tingkat Keberhasilan Hidup Ikan Nila}

Kelulusan merupakan persentase organisme yang hidup pada akhir pemeliharaan dalam jumlah organisme yang ditebar pada saat pemeliharaan dalam suatu wadah. Hasil yang diperoleh terhadap tingkat keberhasilan hidup selama masa pemeliharaan 30 hari dapat dilihat pada Tabel 3 dan Gambar 5.

Tabel 3. Tingkat Keberhasilan Hidup Ikan Nila

\begin{tabular}{cccc}
\hline Perlakuan & No & Nt & SR $(\%)$ \\
\hline KONTROL & 20 & 20 & 100 \\
A & 20 & 19 & 95 \\
B & 20 & 20 & 100 \\
\hline
\end{tabular}

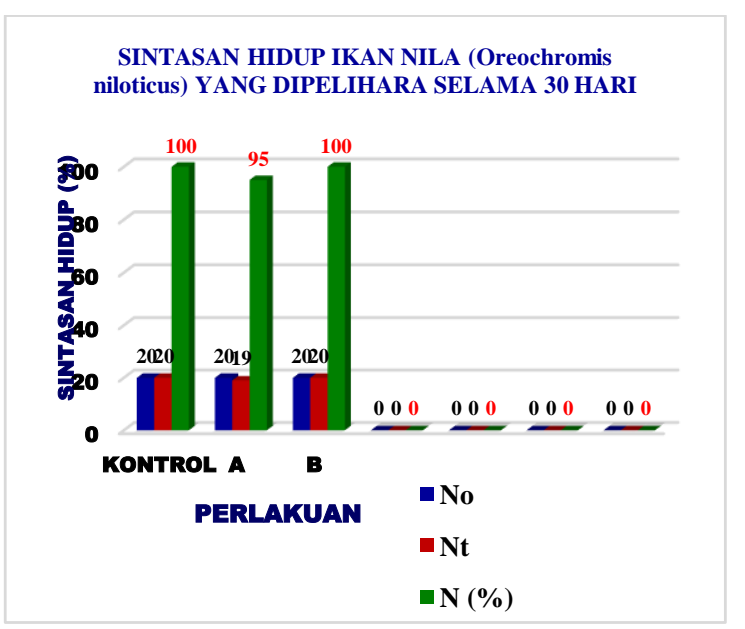

Gambar 5. Tingkat Keberhasilan Hidup Ikan Nila Selama 30 Hari Pemeliharaan

Hasil perhitungan tingkat keberhasilan hidup mempunyai nilai survival rate yang tinggi. Pada Kontrol dan perlakuan B memperoleh nilai Survival Rate yaitu $100 \%$ yang artinya semua benih ikan nila sampai akhir pemeliharaan hidup semua. Sedangkan pada perlakuan A nilai survival rate yaitu $95 \%$. Hal ini dikarenakan pada hari ke-15, ketika mengambil ikan dalam wadah tidak berhati-hati sehingga ikan meloncat keluar dari wadah. 


\section{Kualitas Air}

Hasil pengukuran parameter kualitas air yang diukur dalam pemeliharaan ikan nila yaitu suhu, derajat keasaman $(\mathrm{pH})$, nitrat, nitrit, dan amoniak (dapat dilihat pada Tabel 4.

Tabel 4. Parameter Kualitas Air Dalam Pemeliharaan Ikan Nila Selama 30 Hari.

\begin{tabular}{|c|c|c|c|c|}
\hline \multirow{2}{*}{ Parameter } & \multicolumn{3}{|c|}{ Hari } & \multirow{2}{*}{ Keterangan } \\
\hline & $\mathbf{0}$ & 15 & 30 & \\
\hline Suhu $(\square \mathrm{C})$ & 26 & 28 & 27 & $\begin{array}{c}\text { Dapat } \\
\text { ditoleransi }\end{array}$ \\
\hline $\mathrm{pH}$ & 7.0 & 7.5 & 7.0 & $\begin{array}{c}\text { Dapat } \\
\text { ditoleransi }\end{array}$ \\
\hline Nitrat (mg/l) & 0 & 0 & 0 & $\begin{array}{c}\text { Dapat } \\
\text { ditoleransi }\end{array}$ \\
\hline Nitrit (mg/l) & 0 & 0 & 0 & $\begin{array}{c}\text { Dapat } \\
\text { ditoleransi }\end{array}$ \\
\hline $\begin{array}{l}\text { Amoniak } \\
(\mathrm{mg} / \mathrm{l})\end{array}$ & 0 & 0 & 0,01 & $\begin{array}{c}\text { Dapat } \\
\text { ditoleransi }\end{array}$ \\
\hline
\end{tabular}

Adapun variabel parameter kualitas air yang diukur adalah suhu dan derajat keasaman atau $\mathrm{pH}$, nitrat, nitrit, dan amoniak. Pengukuran suhu dan $\mathrm{pH}$ dilakukan setiap perubahan cuaca seperti dari musim hujan ke panas dan ke musim hujan lagi. Selama masa pemeliharaan 30 hari yaitu suhu air mempunyai kisaran normal yaitu 26$28 \square$ C. Sedangkan derajat keasaman (pH air) yaitu 7 yang artinya masih tergolong normal. Nitrat dan nitrit pada kolam pemeliharaan ikan nila, masih normal sedangkan amoniak yaitu 0,01 yang artinya masih bisa ditoleransi. Hal ini dikarenakan, pipa air yang masuk ke kolam agak deras dan terjadi pengadukan massa air di dalam kolam pemeliharaan sehingga air agak sedikit keruh.

Air merupakan media atau habitat penting bagi kehidupan ikan. Suplai air yang memadai dapat memecahkan berbagai masalah dalam budidaya ikan. Selain itu, kualitas air yang baik merupakan salah satu kunci keberhasilan dalam budidaya ikan. Suhu mempengaruhi ikan seperti pernapasan dan reproduksi. Kualitas air adalah faktor utama dalam keberhasilan budidaya karena air merupakan media hidup organisme perairan dalam menunjang pertumbuhan dan kelangsungan hidup ikan. Parameter air yang penting dalam keberhasilan budidaya, seperti suhu, oksigen, $\mathrm{pH}$, $\mathrm{CO}_{2}$, ammonia, dan nitrit (Ballesteros dan Mendoza, 1972 dalam Hubeis, 1994). Kualitas air merupakan faktor yang sangat penting dalam suatu kegiatan budidaya. Lingkungan hidup yang baik dapat mengoptimalkan pertumbuhan ikan dalam wadah budidaya, sehingga produktivitas kegiatan budidaya dapat meningkat.

Menurut Suyanto (2003) bahwa ikan nila dapat hidup dengan suhu antara $14-38 \square \mathrm{C}$, dan suhu terbaik adalah 25-30 $\square \mathrm{C}, \mathrm{pH}$ air antara 6,0 - 8,5. Sedangkan menurut Ali (2009), bahwa suhu optimal dalam budidaya ikan adalah $28-30^{\circ} \mathrm{C}$. Sarifin et al. (2014), bahwa kadar pH yang baik untuk pembesaran ikan adalah $6.5-8.5$. Suhu air sangat berkaitan erat dengan konsentrasi oksigen terlarut dan laju konsumsi oksigen hewan air.

Suhu air merupakan faktor lingkungan yang berkaitan dengan kemampuan renang ikan (Lee et al. 2003 dalam Hamid et al., 2018). Dalam kisaran suhu toleransi, kecepatan renang suatu spesies ikan akan bertambah dengan meningkatnya suhu air sampai suatu batas maksimum (suhu optimum) dan selanjutnya akan menurun (Beamish, 1978 dalam Hamid et al., 2018), dan kemampuan ini berguna untuk meningkatkan pengambilan makanan (Plaut, 2001 dalam Hamid et al., 2018). Kondisi suhu air yang lebih hangat memungkinkan laju metabolisme, pencernaan makanan, dan pertumbuhan ikan menjadi lebih cepat (Humphries et al., 1999 dalam Hamid et al., 2018).

Kordi dan Tancung (2005) menyebutkan bila suhu rendah ikan akan kehilangan nafsu makan sehingga pertumbuhannya akan terhambat, sebaliknya bila suhu terlalu tinggi ikan akan mengalami stres bahkan mati karena kekurangan oksigen. Hal ini bahwa kisaran suhu selama masa pemeliharaan dinilai masih berada pada

\section{POLITEKNIK NEGERI NUSA UTARA}


kisaran suhu yang normal untuk menunjang pertumbuhan ikan. Pertumbuhan dan kehidupan biota budidaya sangat dipengaruhi oleh suhu air.

Kondisi keasaman suatu perairan dipengaruhi oleh kondisi tanah sekitarnya (Zweigh et al., 1999 dalam Hamid et al., 2018). Organisme akuatik, termasuk kelompok ikan mempunyai toleransi yang berbeda-beda terhadap kondisi pH air. Baldisserotto (2011) dalam Hamid et al (2018) mengemukakan bahwa tingkat keberhasilan hidup dan pertumbuhan ikan umumnya berlangsung di antara nilai pH air 6-9. Apabila ikan terdedah di luar kisaran kondisi pH ini, maka keadaan tersebut akan mengakibatkan aktivitas ikan berenang menjadi menurun, tingkah laku menjadi tidak normal dan cacat, aktivitas makan menjadi tidak aktif, sedikit makanan yang dicerna, dan kehilangan berat tubuh, gangguan pengaturan ion dan kematian (Wilson et al., 1999 dalam Hamid et al., 2018, Nelson, 1989 dalam Hamid et al., 2018).

\section{KESIMPULAN}

Laju pertumbuhan harian tertinggi ikan nila selama 30 hari pemeliharaan terdapat pada perlakuan B. Tingkat Keberhasilan hidup ikan nila pada kontrol dan perlakuan B yaitu 100\%, yang artinya semua ikan uji yang dipelihara hidup semua. Sedangkan pada perlakuan A yaitu $95 \%$, artinya ada 1 ekor ikan yang meloncat keluar wadah.

\section{DAFTAR RUJUKAN}

Afrianto dan E. Liviawaty. 2005. Pakan Ikan dan Perkembangannya. Penerbit. Kanisius. Yogyakarta.

Ali, F. 2009. Mendongkrak Produktivitas Udang Galah Hingga 250\%. Penebar Swadaya. Depok.111 hlm.

Amri, K dan Khairuman 2003. Budidaya Ikan nila secara intensif. Jakarta: PT. Agro Media

Amri, K dan Khairuman. 2008. Buku Pintar Budidaya 15 Ikan Konsumsi. Penerbit PT. Agromeia Pustaka : Jakarta.
Anonim. 2009. Badan Standarisasi Nasional. SNI: 6138. Induk Ikan Nila Hitam (Oreochromis niloticus Bleeker) kelas induk Pokok (Parent Stock). 5 halaman.

Budiarto, H. 1991. Stabilitas Antosianin (Garcinia mangostana) Dalam Minuman Berkarbonat. ITB Bogor.

Cho , C.Y.C, B. Cowey, dan R. Watanabe. 1985. Finfish Nutrition In Asia : Methodological Approaches Research Center. Ottawa. 154 p.

Cronquist, A. 1981. An Integrated System of Classification of Flowring Plants. New York, Columbia University Press.

De Silva, Anderson. 1995. Fish Nutrition in Aquaculture. Penerbit Harpman dan Haall. London.

Dwidjoseputro. 1986. Biologi. Penerbit Erlangga. Jakarta.

Effendie M.I. 1997. Biologi Perikanan. Penerbit Yayasan Pustaka Nusantara. Yogyakarta. 163 hal.

Ekawati, S. R. 2008. Peningkatan Sintasan dan Pertumbuhan Kepiting Bakau Scylla olivacea Stadia Zoea Melalui Aplikasi Pakan Alami Hasil Bioenkapsulasi Karotenoid Cangkang Kepiting Non Ekonomis. Tesis. Program Pascasarjana Ilmu Perikanan. Universitas Hasanuddin. Makassar. 106 hal.

El-Sayed, A. F.M. 2006. Tilapia Culture. Wallingford, Oxfordshire, UK : CABI Publishing is a Division of $\mathrm{CAB}$ International.

Fujaya, Y., 2004. Fisiologi Ikan. Penerbit Rineka Cipta. Jakarta

Halver, J. E. 1989. Fish nutrition. Second edition. Academic Press Inc. California.

Hamid H, Asriyana, Eko Prianto, Manangkalangi E, Yoga G.P, Haryono, Sudarso J, Gundo M.T, M.F Raharjo, Pertami N.D. 2018. Ekologi Reproduksi dan Pertumbuhan Ikan. Penerbit PT. IPB Press. Bogor. 229p.

Hubeis, M. 1994. Pemasyarakatan ISO 9000 untuk industri pangan di Indonesia. Buletin Teknologi dan Industri Pangan. Vol. V (3). Fakultas Teknologi Pertanian. IPB Bogor.

Ilyas S, F. Cholik, A. Poernomo, W. Ismail, R. Arifudin, T. Daulay, A. Ismail, S. Koesoemadinata, I.N.S. Rabegnatar, H. Supriyadi, H. H. Suharto, Z. I. Azwar, dan S.E. Wardoyo. 1987. Petunjuk Teknis Bagi Pengoperasian Unit Usaha Pembesaran Udang Windu. Pusat Penelitian dan Pengembangan Perikanan. Jakarta. 99 hal. 
Isnansetyo, A., Kurniastuti. 1995. Teknik kultur phytoplankton dan zooplankton. Penerbit Kanisius. Yogyakarta.

Kordi dan Tancung. 2005. Budidaya Ikan Laut Keramba Jaring Apung. Rineka Cipta. Jakarta

Lagler, K. F., J. E. Bardach dan R. R. Miller. 1962. Icthyology. John Wiley and Sons, New York.

Lovell, T. 1989. Nutrition of Fish . Van Nostrand Reinhold. New York. 260 p.

Mansyah Elina, Sobir, R. Poerwanto, E. Santosa, dan S. Sinaga. 2011. Genetic Variability In Apomictic Mangoesteen (Garcinia mangostana) and Its Close Realtives (Garcinia spp.) Based On ISSR Markers. Volume 12. Pages : 59-63. Bogor.

Mardawati E, Achyar CS, dan Marta H. 2008 Kajian aktivitas antioksidan ekstrak kulit manggis (Garcinia mangostana) dalam rangka pemanfaatan limbah kulit manggis di Kecamatan Puspahiang Kabupaten Tasikmalaya. Bandung.

Mardiana, L. 2012. Ramuan dan Khasiat Kulit Manggis. Jakarta : Penebar Swadaya.

Meyers, S.P dan T. Latscha, 1997. Carotenoid : Crustacean Nutrition. World Aquaculture. 6:321327.

National Research Council. 1983. Nutrient Requirments of Warm Water Fishes and Shellfishes. National Academy Press. Washington DC.

Permana, A.W. 2010. Kulit Buah Manggis Dapat Menjadi Minuman Instan Kaya Antioksidan. Warta Litbang Deptan. 32(2) : 3 .

Puspitasari L, Swastini, dan Arisanti, C.I.S. 2013. Skrining fitokimia ekstrak etanol 95\% kulit buah manggis (Garcinia mangostana). Vol. 2, No. 3. Jurnal Farmasi Udayana.
Qosim, W.A. 2007. Kulit Buah Manggis sebagai Antioksidan. Bandung.

Sallata, M. K. 2015. Konservasi dan Pengelolaan Sumber Daya Air Berdasarkan Keberadaannya Sebagai Sumber Daya Alam. Info Teknis Eboni, Vol. 12 No. 1 : 75-86.

Santoso, B. 1996. Budidaya Ikan Nila. Penerbit Kanisius. Yogyakarta.

Sarifin, K.T. Wibowo, D. Rohmana, S. Rosellia. 2014. Untung $100 \%$ dari Budidaya Udang Galah. Agromedia Pustaka. Jakarta. $120 \mathrm{hlm}$.

Suksamrarn, S, 2003. Antimycobacterial activity of prenylated xanthones from the fruits of Garcinia mangostana. Chem Pharm Bull. Tokyo.

Suyanto. 1993. Nila. Penerbit Penebar Swadaya. Jakarta.

Thomas, A. 2005. Aspek Biologi Pertumbuhan, Reproduksi, dan Kebiasaan Makan Ikan Nila (Oreochromis niloticus). IPB. Bogor.

Webster, C. D., and C. Lim. 2002. Nutrition requirenment and feeding finfish for aquaculture. CABI Publishing. New York. USA

Yue, G. H., Lin, H., dan Li, J. 2016. Tilapia is the fish for next Generation aquaculture. International Journal of Marine Science and Ocean Technology , 3(1), 11-13

Zonneveld, N., Huisman E.A., dan Boon J.H. 1991. Prinsip-Prinsip Budidaya Ikan. Gramedia Pustaka Utama. Jakarta. 